\title{
Eleanor Roosevelt's Tax Returns
}

\author{
Carolyn C. Jones
}

On September 23, 1952, vice presidential candidate Richard Nixon delivered his now famous "Checkers Speech." Accused of improper use of a fund set up by California donors, Nixon knew his position as Dwight D. Eisenhower's running mate was on the line. In reaction to a number of scandals plaguing the Truman administration, the 1952 Republican campaign had been built around promises to remedy corruption. But the accusations against Nixon endangered that theme. Confessing that the Nixons had kept a gift cocker spaniel (Checkers), and memorably referencing his wife's "respectable Republican cloth coat," Nixon laid out some of his family's finances "before the American people" and then challenged his opponents to do the same. "If they don't," he argued, "it will be an admission that they have something to hide." In reaction to the speech, President Truman invoked his year-old proposal to require federal officials to disclose outside income. ${ }^{2}$ Adlai Stevenson and his running mate in turn announced that they would make public the past ten years of their income tax returns. ${ }^{3}$

But former First Lady Eleanor Roosevelt disapproved of these developments. "Everybody," she wrote in her "My Day" column, "is now disclosing his income tax returns ... my old friend, the former Secretary of the Treasury, Henry Morgenthau, Jr., argued with me the other day that this was the only thing that could be done really to give us back a sense of morality in government." She disagreed. ${ }^{4}$

To many Americans, it now seems obvious that income tax disclosure by presidents and presidential candidates-a norm since Nixon was president-unequivocally serves the public good, acting as a bulwark against corruption and a mark of transparency. In April 2017, thousands joined Tax Marches across the nation to protest President Trump's break with that tradition. But Eleanor Roosevelt saw more at stake in such disclosure. Pitted against transparency, she saw the competing right to cultivate privacy and personal independence, values which, as Roosevelt knew well, affected women in very particular ways given the gendered history of earning money and paying taxes. Did compulsory tax return disclosure create a sort of presumption of guilt, stoking distrust and suspicion in the same way that loyalty oaths did? Just what should the public know about their representatives' finances and those of their families?

Before the late twentieth century, various attempts to make federal taxpayer information public had proved short-lived. The Civil War income tax permitted public inspection of returns, which resulted in newspaper publication of filings by prominent citizens, but the policy was repealed shortly before the income tax itself expired in 1872. After the revival of federal income tax on individuals in 1913, and on the heels of the Teapot Dome affair and other Harding administration scandals, in 1924 Congress once again enacted individual taxpayer

\footnotetext{
The author would like to thank Laura Moon for her research assistance.

${ }^{1}$ Richard Nixon, "Address of Senator Nixon to the American People: The 'Checkers Speech," Sept. 23, 1952, American Presidency Project, http://www.presidency.ucsb.edu/ws/index.php?pid=24485 (accessed Mar. 27, 2018).

2"Truman Is Silent on the Two Funds," New York Times, Sept. 26, 1952, 14. Within a month, three of the four principal candidates had publicized their income tax returns. "Forecast Cloudy," New York Times, Oct. 19, 1952, E1.

${ }^{3}$ W. H. Lawrence, “Stevenson Camp Counts Nixon Affair an Asset,” New York Times, Sept. 28, 1952 , E5.

${ }^{4}$ Eleanor Roosevelt, "My Day,” Sept. 29, 1952, Eleanor Roosevelt Papers Project, https://www2.gwu.edu/ erpapers/ myday/displaydoc.cfm?_y=1952\&_f=md002339 (accessed Mar. 27, 2018).

(C) The Author(s) 2018. Published by Cambridge University Press
} 
publicity, subjecting names, addresses, tax paid, and refund amounts to inspection, and the United States Supreme Court upheld the right of newspapers to publish such information. ${ }^{5}$ In 1926, however, the Coolidge administration successfully limited publicity to only the name and addresses of those filing returns. ${ }^{6}$

The "soak the rich" atmosphere of the Great Depression revived yet again pressure for tax publicity, which could shine a spotlight on the wealthiest Americans and their taxpaying habits. Publication of taxpayer information, many argued, allowed citizens to detect cheating and "maladministration" by tax officials as well as prevent tax evasion among the top 10 percent of the population who were then obligated to file returns. In 1934, legislation passed requiring that a publicly available "pink slip" be attached to each return with name, address, total gross and net income, deductions, credits, and liability. ${ }^{7}$ But the policy immediately drew backlash from opponents who argued that pink slips represented an invasion of privacy, could harm small businesses, reveal trade secrets, or-the Lindbergh baby murder case was being tried at the time-facilitate kidnapping and other crimes. In 1935, the policy was once again repealed. ${ }^{8}$

Still, the decade's revenue shortfalls and other economic troubles kept the issue in view. In 1936 a series of revelations suggested that some taxpayers were using personal holding companies to generate losses from sales of stock among family members and for other unintended purposes. One millionaire set up a personal holding company to own his yacht and some securities. He rented the yacht from his holding company and then used the income from the securities (taxed at a lower rate than if he held them himself) for the maintenance and staffing of the ship. News of such tax avoidance techniques enraged Franklin D. Roosevelt, who famously styled himself as the enemy of "economic royalists." Urging the creation of a Joint Committee on Tax Evasion and Avoidance to investigate such loopholes, he declared: "The time has come when we have to fight back, and the only way to fight back is to begin to name names of these very wealthy individuals who have found means of avoiding their taxes both at home and abroad." 10 FDR was prevailed upon not to release the names of tax "cheats" himself, but soon the Commissioner of the Internal Revenue listed sixty-seven "large, wealthy taxpayers" who had avoided contributing "their full shares of taxes." Most of them were Republicans. ${ }^{11}$ They may have used legal devices, but New Dealers cast their actions as an immoral evasion of civic duty.

Before long the scrutiny boomeranged back on the president as congressman Hamilton Fish (R-NY) set out to expose irregularities in Roosevelt's own returns. On the floor of the House, Fish accused FDR of taking depreciation on a barn at his Hyde Park estate built in 1790 and purchased by the President in $1910 .{ }^{12}$ Fish wanted the investigative committee to look into FDR's other farm losses in New York and Georgia, as well as rental payments on a Hyde Park property to FDR's mother by the federal government. ${ }^{13}$ FDR produced documents for Congress in his own defense, and Fish was barred from publicly discussing the President's return, so the congressman shifted his fire to Eleanor Roosevelt and her sons instead.

\footnotetext{
${ }^{5}$ United States v. Dickey, 278 U.S. 378 (1925).

${ }^{6}$ Mark Leff, The Limits of Symbolic Reform: The New Deal and Taxation, 1933-1939 (Cambridge, UK, 1984), 72-3.

${ }^{7}$ Lawrence H. Seltzer, The Personal Exemptions in the Income Tax (New York, 1968), 62.

${ }^{8}$ Marjorie E. Kornhauser, "Shaping Public Opinion and the Law: How a 'Common Man' Campaign Ended a Rich Man's Law," Law and Contemporary Problems, no. 73 (Winter 2010): 123-48, here 123; Joshua D. Blank, "In Defense of Individual Tax Privacy," Emory Law Journal, no. 61 (2011): 265-348, here 265.

${ }^{9}$ Samuel I. Rosenman, ed., The Public Papers and Addresses of Franklin D. Roosevelt, Vol. V: The People Approve, 1936 (New York, 1938), 234, 568.

${ }^{10}$ John Morton Blum, From the Morgenthau Diaries, Vol. I: Years of Crisis, 1928-1938 (Boston, 1959$), 327$.

${ }^{11}$ U.S. Congress, Joint Committee on Tax Evasion and Avoidance, Hearings, Part 3, 75 Cong., 1st sess., July 9 and 13, 1937 (Washington, DC, 1937), 335.

12“President Uses Tax Loopholes, Says Rep. Fish," Chicago Daily Tribune, July 1, 1937, 35.

13“Repeats Demand 'Look Into Taxes Roosevelts Pay,"' Chicago Daily Tribune, June 20, 1937, 12.
} 
Fish discovered that Mrs. Roosevelt had a broadcasting contract that specified an annual income of $\$ 1$ to her and $\$ 3,000$ paid directly to the American Friends Service Committee. The First Lady did not report the portion paid to charity, an arrangement Fish viewed as violating tax laws. ${ }^{14}$ Robert H. Jackson, counsel for the Internal Revenue Bureau and later Supreme Court Justice and Chief Prosecutor at Nuremberg, defended Roosevelt and ruled that her assignment of the untaxed proceeds to charity was permitted. ${ }^{15}$ Although triggered by reasonable questions about the social obligations of the wealthy, this unpleasant back and forth, the threatened exposure for Eleanor Roosevelt, her mother-in-law, and some of her children could not have created a favorable impression of the possible collateral damage of Presidential tax disclosure.

The brief incident before the Joint Committee also provided insight into Eleanor Roosevelt's complicated relationship with her husband and role as First Lady. Part of a marriage of two distinct personalities, scarred by his infidelity and her consignment, at times, to a lesser role among his advisors, Eleanor Roosevelt feared that being First Lady would jeopardize the activist identity she had cultivated since the 1920s as well as deprive her of privacy and intimacy with her circle of friends.

At the same time, however, she also leveraged her position in the White House to cultivate a fair degree of independent power. Roosevelt lobbied her husband with missives in his bedtime inbox and built her own extensive political networks. She also valued her ability to earn money to support her own causes and projects. During the 1920s, she had owned a furniture manufacturing factory at Val-Kill, founded the Todhunter School, and wrote many paid articles, lectures, and radio addresses. As First Lady she capitalized further on her reputation and celebrity. So successful that her income sometimes exceeded her husband's salary, Roosevelt continued to make paid endorsements for airlines, mattresses, Good Luck margarine, and other products throughout her life. Her income symbolized personal achievement. Filing tax returns-and, it seems, filing them separately from Franklin-did as well. ${ }^{16}$

Having control over their own tax returns meant something to women like Eleanor Roosevelt. Thus it was no surprise that she raised concerns when the House of Representatives considered an amendment to require mandatory joint returns for married couples in the summer of 1941. Residents of community property states and those using some other tax schemes were often able to reduce liability through income splitting, but with military pressures building in 1941, the Roosevelt administration hoped to increase revenues by combining more spouses' incomes in joint returns. Yet strong opposition emerged not only from conservatives and legislators from community property states but also from female activists who characterized the proposal as "a step backward in a world which can ill afford further retrogressions." Judge Dorothy Kenyon called it "a Hitlerian concept ... to further discrimination against women."17 Eleanor Roosevelt agreed and urged consideration of other tax-raising alternatives, describing the mandatory joint return as one that "strikes at the roots of a fundamental principle ... the right of women to be considered as persons." ${ }^{18}$ Only a year later, faced with the

\footnotetext{
${ }^{14}$ Joint Committee on Tax Evasion and Avoidance, Hearings, Part 3, 334-8. The Roosevelts' son, James, had to testify before the committee as to whether he had a foreign personal holding company. He was asked to submit his income returns for a five-year period after he went into the insurance business in Massachusetts. Ibid., 351-4.

${ }^{15}$ Statement of Assistant Attorney General Robert H. Jackson, Joint Committee on Tax Evasion and Avoidance, Hearings, Part 3, 417-8.

${ }^{16}$ Maurine H. Beasley and Henry R. Beasley, "Eleanor Roosevelt as an Entrepreneur," in White House Studies Compendium, vol. IV, ed. Robert W. Watson (New York, 2007), 455-67.

${ }^{17}$ Arthur Krock, "Mrs. Roosevelt's Conversion to Joint Tax Returns," New York Times, June 9, 1942, C22. See also Edward J. McCaffery, Taxing Women (Chicago, 1999); and Carolyn C. Jones, "Split Income and Separate Spheres: Tax Law and Gender Roles in the 1940s," Law and History Review 6, no. 2 (Autumn 1988): 259-310.

${ }^{18}$ Eleanor Roosevelt, "My Day," Aug. 7, 1941, Eleanor Roosevelt Papers Project, https://www2.gwu.edu/ erpapers/ myday/displaydoc.cfm?y=1941\&_f=md055958.
} 
determination of others in the Roosevelt administration and the growing exigencies of war, did Eleanor Roosevelt relent and support the idea of mandatory joint returns. Countering the notion that the proposal "would undermine a working wife's independence," she cast her change of heart in terms of civic wartime duty. The Roosevelts would probably pay more taxes, she said, but "Uncle Sam would benefit at a time when he needs the money for warships and planes." 19

The 1942 proposal failed as well, but the controversy illustrated the complex meanings of tax returns-as somehow both private documents and public performances, as personal declarations as well as family and social compacts. This history helps explain Roosevelt's reticence in 1952 to Nixon's call for politicians to disclose their filings. Public disclosure might root out corruption or undue influence. (Indeed, Nixon's own returns demonstrated massive evasion). ${ }^{20}$ But releasing such information as a matter of course, Eleanor Roosevelt worried, also fueled an atmosphere of political polarization, inquisition, and suspicion. Acknowledging the arguments in favor of disclosure, she wrote:

Still, I cannot help regretting that, in order to show our belief in morality, public and private, we feel it necessary to give up all privacy. My real feeling against asking all government officials to reveal their finances goes further, however. I am against it because it is a sign that we no longer believe people should be proved guilty before they are accused of wrongdoing. The same holds good for signing loyalty oaths, over and above the ordinary oath of allegiance all officials ordinarily take. ${ }^{21}$

The role of money in American politics has grown dramatically since Eleanor Roosevelt's day. Yet sixty-five years later, Americans are still weighing transparency against privacy, and trying to balance worries about corruption against the need for trust.

Carolyn C. Jones is the Orville L. and Ermina D. Dykstra Chair in Income Tax Law at the University of Iowa College of Law and the former dean at the College. Her research interests are in the twentieth century history of the United States tax system and its legitimacy, and in the intersection of feminism and tax policy in the United States.

\footnotetext{
19“Mrs. Roosevelt Backs Joint Income Return," New York Times, June 9, 1942, 18.

${ }^{20}$ Joseph J. Thorndike, “JCT Investigations of Nixon's Tax Returns," Tax Notes, June 13, 2016, 1527.

${ }^{21}$ Roosevelt, “My Day,” Sept. 29, 1952.
} 